\title{
ИСТОРИЯ ПРАВА
}

Кочетков В.В.

\section{СВОБОАА ИАИ СПРАВЕААИВОСТЬ: \\ АИСКУССИЯ Б. Н. ЧИЧЕРИНА И В. С. СОАОВЬЕВА О СУЩНОСТИ ПРАВА И СОВРЕМЕННЫЙ КОНСТИТУЦИОНААИЗМ}

\begin{abstract}
Аннотация. Предметом настоящей статьи является полемика Б. Н. Чичерина и В. С. Соловьева по вопросу о сущности права, развернувшаяся во второй половине ХІХ века. Если первый был классический миберал, связывавщий сущность права исключительно с иенностью свободы, то второй отстаивал понимание права как некоторого минимума справедливости. Разбирая их взгляды, автор статьи показывает, что аргументы этих ученых широко распространены среди современных российских правоведов. К сожалению, в современной отечественной правовой науке до сих пор не найден консенсус по этому принципиальному вопросу. В настоящей работе используется метод единства исторического и логического в сочетании с историко-критическим методом, что позволяет актуализировать теоретическое наследие Б. Н. Чичерина и В. С. Соловьева. От понимания сущности права напрямую зависит содержание законодательства и правоприменение в современном государстве. Аля того чтобы снять оппозицию свободы и справедливости автор предлагает аксиологическое понимание конституиионализма как теоретической формы правосознания, соединяющей эти ценности в творческом синтезе. На этой основе возможно имплементаиия норм и приниипов Конституции 1993 года в ткань российского общества.
\end{abstract}

Ключевые слова: конституицонализм, Борис Чичерин, Владимир Соловьев, правосознание, свобода, справедмивость, право, нравственность, ценность, аксиология.

Review. The subject of the present article is the debate between Boris Chicherin and Vladimir Solovyov on the essence of law that took place in the second half of the XIX century. While the former was a classical liberal, who linked the essence of law solely with the values of freedom, the latter defended the understanding of law as some minimum of justice. Examining their views, the author shows that the arguments of these scholars are widespread among modern Russian jurists. Unfortunately, modern domestic legal science has not yet found a consensus on this fundamental issue. In the present paper the method of the unity of the historical and logical, together with the historical critical method are used, which allows to update the theoretical heritage of Boris Chicherin and Vladimir Solovyov. The content of the legislation and legal enforcement in the modern state directly depend on how we understand the nature of law. In order to remove 
the opposition of freedom and justice, the author proposes axiological understanding of constitutionalism as a theoretical form of legal consciousness, linking these values in a creative synthesis. On this basis it is possible to implement the norms and principles of the 1993 Constitution into the fabric of the Russian society.

Keywords: justice, freedom, legal consciousness, Vladimir Solovyov, Boris Chicherin, constitutionalism, law, moral, value, axiology.

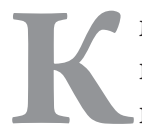

моменту первой постановки в России в 70-е годы XIX века конституционного вопроса (который можно определить как когнитивный Аиссонанс межАу рационально выраженными ценностями свободы, справеАливости и человеческого достоинства, с оАной стороны, и отсутствием реальных условий Аля их реализации на практике, с Аругой) на Западе уже сложились три мощные традиции конституционализма как опредеменной формы правосознания. Первая, её условно можно называть англосаксонской, считала, что приоритетом госуАарственного управцения явцяется защита прав и свобод гражАанина, что единственным основанием власти явмяется учреАительный общественный Аоговор на базе признания равного достоинства за всеми мюдьми. Осевым принципом построения госуАарства явмялось ограничение его вмешательства в пространство частной и публичной автономии. ОтсюАа большое внимание, которое УАемялось ограничению государственной власти: или через механизм преАставительного самоуправмения своими делами самим народом, естественно, при наличии системы независимых и справедливых судов (парламентская монархия в Англии); или через механизм разделения вмасти, как по вертикали, так и по горизонтали, по полномочиям и способам мегитимации (известен как система сдержек и противовесов), но опять-таки при наличии независимого и справеАливого суда в качестве гаранта функционирования всей системы (североамериканская федеративная республика).

Вторая - французская — модель конституционализма отмичалась от первой тем, что государство уже не несло на себе печать учредительного общественного договора. Оно наоборот само создавало нацию путем признания равного достоинства за всеми гражАанами, что, прежде всего, выражалось в признании естественных и неотчуждаемых прав человека. ЕАинственным способом обеспечить это считался принцип последовательного раздемения властей, который приводил к тому, что суА уже не являлся гарантом функционирования всей системы, а таковым считалась воля нации, которая вырабатывалась или в парламентских дебатах, или методом плебисцитарной демократии, или в революционном творчестве. Иначе говоря, межАу госуАарством и гражАанином появмялось третье Аицо - политическая нация и её вомя в качестве источника мегитимации госуаарственной власти. Можно сказать, что во Франции в процессе рационализации базовых ценностей конституционного правосознания были соеАинены традиции абсолютистского государства (аАминистративная юстиция-справедливость) и принцип народного суверенитета с его комлективной защитой прав человека (солидарность как братство).

Иначе складывался процесс рационализации ценностей конституционного правосознания в Германии, на которую традиционно в сику определенных культурных и Аинастических связей была сориентирована как правительственная бюрократия, так и интемлигенция Российской империи. Поскольку процесс становления германского государства носии во многом искусственный характер, постольку среАи немецких интемлектуалов роАились Аве теории, которые оказали сильнейшее влияние на историю как Европы в целом, так и России в частности. Мы имеем в виду понятие народного духа как субстанции права и теорию государства как особого юриАического мица. Первая концепция поскужила обоснованием особого немецкого пути (Sonderweg) как последовательного вопиощения народного Ауха, которая, в конечном счете, привела весь мир к трагеАии национал-социализма. Аругая породила идею о возможности существования правового государства как государства, ограниченного своим собственным правом, то есть, по сути Аела, законами им создаваемыми. Это была особая немецкая рационамизация англосаксонского принципа верховенства права, которая в конечном итоге привека к юриАическому позитивизму, заменяющему принцип справеАливости в качестве источника права волей облеченного властью (юридического ими физического) мица.

Сближало Германию и Россию также то, что Алительное время эти страны находились на периферии социального и экономического развития Европы. ОтсюАа некоторый иррационализм теорий народного Ауха (вместо рационализма идеи прав человека или народного суверенитета) и правового самоограничения государства как юридического мица (вместо рационализма верховенства права как примата права на частную и публичную автономию). Поэтому распространение ценностей конституционного правосознания в России того времени стац- 
кивалось с несколькими препятствиями. Во-первых, это неприятие права в качестве основного способа общественной саморегумяции. Аргументы такого рода активно разрабатывали мыслители славянофильской ориентации. Славянофилы ставили в вину Западу его юридический рационализм. Они считали, что самодержавие и православие Аелают русский народ настолько отличным от народов Аругой (катомической и протестантской) христианской Европы, что никакие заимствования политических и юриАических институтов вообще невозможны. А если и возможны, то они неизбежно привеАут русский народ к вырожАению, а страну к гибели.

Во-вторых, необходимо учитывать, что к моменту первой постановки конституционного вопроса в отечественной истории российские мыслители находились поА сильным влиянием запаАной социалистической критики буржуазного общества, что Аишь, естественно, усиливало их антиконституционные преАрассуаки. «Русские революционеры, поняв, что изменение формы правления не могло решить мучительных социацьных проблем, поспешили уверить в то, что они - не «буржуазные революционеры», что их революция, в отличие от западных политических революций, не будет служить интересам буржуазии. ... Это объясняет тот Аюбопытный факт, что революционеры в России, стране, которая много пострадаяа от своей автократической политической системы, стали так непреклонны и упрямы в своем презрении к конституционным гарантиям прав человека и «обманчивой» политической свободе Запада». ${ }^{[1,84]}$ В силу этого, все обоснования конституционализма в России Аолжны были осуществлять своеобразный синтез миберализма и социализма.

В-третьих, самодержавие как таковое созАает очень благоприятные условия Амя распространения юридического позитивизма. Аюбой закон в России того времени име характер Аара со стороны неограниченного монарха. Аобровольность Аара имела своим следствием некоторое самообязывание русского самодержца. Кроме того, российский император быи ограничен традицией, то есть правовым материалом, созданным его преАшественниками. Максимум того, что он мог себе позволить, это систематизация законодательства, которая была впервые осуществиена М. М. Сперанским по поручению Никомая I.

B-четвертых, поскольку русское самодержавие (и это обратная сторона юриАического позитивизма) ассоциированась с произволом, то среди всех слоев российского населения был распространен правовой нигилизм. Причиной этого также было и то, что в России не было Аолгое время независимых профессиональных юристов (хотя у самодержавия и было намерение построить хорошо функционирующее полицейское госуАарство). Фактически этот слой начал только формироваться в эпоху Великих реформ. Аругим западным источником русского «правового нигилизма» было илеологическое поражение веры в разумное законодательство - веры, которая была свойственна не только просвещенным монархам восемнадцатого века, но, в большей степени, революционерам этого времени. Широко распространенное разочарование в результатах цемого ряда французской революций вызвало почти всеобщее отрицание рационалистического подхода к общественному переустройству, а также рационамистической теории прав человека.

В этих особых исторических условиях при рационализации ценностей конституционного правосознания, прежАе всего, необходимо было показать внутреннюю связь права и свободы, а также обосновать независимость права от силы (властной санкции) и его зависимость от интерсубъективных преАставлений о справеАливости.

Первый крупный русский правовеА миберального толка Б.Н. Чичерин (1828-1904) определял право как свободу, определенную (или ограниченную) законом. Право Аля него в субъективном смысле - это законная свобода Аелать что-либо или требовать чего-либо, а право в объективном смысле - это система законов, опредемяющих свобо-

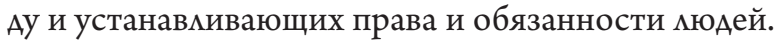
Согласно Б. Н. Чичерину, свободу можно понимать мибо как внешнюю, то есть как сферу индивидуаць-

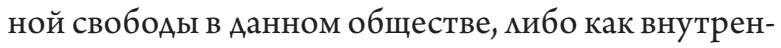
нюю, нравственную свободу. ${ }^{[2,3-9]}$ В первом смысле она имеет отрицательный характер, это свобода от принужАения, независимость от произвольной воли Аругих АюАей; во втором смысле она означает рациональную и нравственную автономию.

ОАнако Аальнейшие рассужАения привеки Б. Н. Чичерина к Аовольно неожиАанным выводам: внешнюю свободу никога не следует отвергать во имя моральных или каких-либо еще соображений. Хотя высшая, нравственная свобода - это свобода Аобра, оАнако нравственность невозможно внеАрить По принужАению. Поэтому свобода Аелать змо - свобода быть нравственным или безнравственным ${ }^{[3,50-52]}$ - есть необходимое условие свобоАы как самоопределения и самосовершенствования. Социально приемлемые границы этой внешней свободы, устанавливаются государством. Очевидно, что как и все классические мибералы того времени, Б. Н. Чичерин считал следующее положение неоспо- 
римым: «Полным выражением юридических начах, без всякой посторонней примеси, явмяется право частное, или гражАанское. ЗАесь человек преАставляется как свободное, самостоятельное мицо, которому присваивается известная область материальных отношений и которое состоит в опреАеленных юриАических отношениях к Аругим таковым же мицам. По самой природе этих отношений в этой сфере господствует инАивиАуализм; зАесь находится главный центр человеческой свободы». ${ }^{[2,88-89]}$

Понимание приоритета прав человека привоАило Б. Н. Чичерина к столкновению со сторонниками неограниченного народного суверенитета, пусть Ааже и в форме прямой и последовательной Аемократии. Почему? «Понимание свободы как участие в принятии политических решений Аолжно было усилить тенАенцию к расширению области политических решений и тем самым - к ограничению частной, неконтролируемой сферы жизни. Таким образом, политическая свобода - свобода в публичной сфере - постепенно поглощала инАивидуальную свободу. Политическая Аемократия, ранее понимаемая как институционная защита инАивиАУацьной свободы, становимась самоцемью, полностью обнажая свой чисто комлективистский характер». ${ }^{[1,170]}$ Поэтому этот правовеА всегда выступац за преАставительное правление как правление кучших и Аостойных. Б. Н. Чичерин преАставлял парламентское правление естественным слеАствием развития каждой нации и конечным этапом политического развития человечества. ${ }^{[4,175]}$

В чем же сущность человека как абсолютного начала? «Свобода (независимость от принужАающего произвола Аругого), поскольку она совместима со свободой кажАого Аругого, сообразной с всеобщим законом, и есть это еАинственное первоначальное право, присущее каждому человеку в силу его принадлежности к человеческому роду». ${ }^{[3,107]}$ Некоторые ученые, например А. Вацицкий, полагают, что такое понимание права как законной свободы, мишает государственную вцасть позитивных целей и Ааже может вести к разрушению при таком Аоминировании частных интересов всей системы госуправления. «Если право неотАелимо от свобоАЫ мичности, то отсюда следует, что оно не Аолжно заниматься целями человеческой деятельности. Его поАлинная функция состоит в формулировании общих начам поведения, а не в установмении

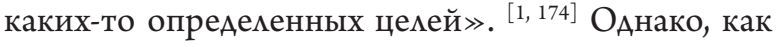
нам преАставляется, такой вывод явцяется сицьным упрощением взглядов Б. Н. Чичерина. Сам он писац по этому поводу следующее: «Право ставит необходимые преАелы кичной свободы, но внутри этих границ мичность Аолжна иметь полную свобоАу в исполнении собственных целей. ... [ОАнако - В.В.К.] Публичное право занимается не свободой кичности, но общественными обязанностями, и поэтому оно не может независимым от цемей; всякий отАельно взятый гражАанин АОлжен иметь свободу исполнения своих собственных, свободно избранных целей, но чиновник не Аолжен использовать свое положение в мичных цемях». ${ }^{[5,175]}$

В этой связи преАставцяется важным понимание Б. Н. Чичериным отличия моральных заповедей от правовых норм. Он считац, что юридический закон определяет внешние границы свободы, в то время как закон морацьный определяет внутренние требования нравственного Аолга. Правовое определение границ свободы не разрушает автономии индивида, а, напротив, очерчивает определенную сферу, в которой жизнь инАивиАа не поАлежит вмешательству государства, и в которой он может быть нравственным или аморахьным. Напротив, правовое определение морацьных обязанностей несовместимо со свободой совести и, слеАовательно, с нравственностью. Нам преАставцяется, что такая контрадикторная оппозиция морали и права у Б. Н. Чичерина носила печать полемики с морализаторством славянофилов. Он хотец показать, что частная автономия имеет важнейшее значение Аля свободы человека, в том числе, Ааже если человек не соответствует госпоАствующим в Аанный момент времени представлениям о морали.

Такое освобожАение правовой свободы от морали также приводило Б. Н. Чичерина и к антисоциалистическим взглядам на проблемы социальной справедиивости. Он полагал, что решение социальных проблем Аолжно осуществляться наряду с совершенствованием индивидуальных нравственных норм: богатые имеют морацьный Аолг помочь беАным, но у бедных нет законного права требовать такой помощи. Б. Н. Чичерин признавац, что госуАарство может помогать беАным, но мишь в искиючительных случаях и чисто благотворительно. Оно ни в коем случае не Аолжно институционализировать эту помощь как преАмет законных обязательств и не может требовать Аля этих целей Аополнительных сумм от своих налогоплательщиков. Иначе говоря, поскольку право и нравственность суть разцичные способы общественной регумяции, постольку государство не Аолжно принужАать к нравственности, так как это означамо бы вторжение его в сферу частной автономии. Но при этом он само не Аолжно быть аморально, то есть практиковать произвоц, нарушая частную и публичную автономию гражАан. Амя права, по мнению Б.Н. Чичерина, наивысшая 
норма - это закон правды, то есть требование возАавать каждому свое. В то время как у морали есть закон Аюбви, который предписывает человеку жертвовать собой на пользу ближнего.

Принципиальным оппонентом классического миберала Б.Н. Чичерина (кстати говоря, еАинственного в своем роде русского конституционалиста) был мыслитель В. С. Сомовьев (1853-1900), который своей фимософией права оказал огромное влияние на рецепцию архетипов конституционного правосознания. В принципе он быц согласен, что илея свободы и права генерируются товарно-денежными отношениями, то есть в сфере частного права. «В сфере конкурирующих экономических интересов АюАи рассматриваются мишь как среАство; поэтому экономический поряАок Аолжен быть подчинен Правовому, в котором АюАи выступают как мичности, субъекты прав и обязанностей (а не оАних только интересов), обеспечивая тем самым установление справеАливости». ${ }^{[6,144]}$ Иначе говоря, право, по В.С. Соловьеву, регумирует отношения меЖАУ свобоАНЫМи Аичностями, Носителями Прав. Поэтому оно Аолжно признавать, принимать, так сказать, как самоочевидное свободу удовлетворять свои собственные интересы и равенство в уважении свободы и интересов Аругих. Основной задачей права на зрелой стадии развития явцяется защита равной свободы ими, иначе говоря, ограничение свободы раАи равенства. Таким образом, заключает В.С. Соловьев, право можно определить как «синтез свободы и равенства» или как «свободу, обусловленную равенством». ${ }^{[6,153]}$ И с этой точки зрения, кмассический миберамизм прав: у размичных инАивиАуумов разАичные интересы, право Аолжно защищать их равную свободу и поэтому не может подАерживать оАни интересы против Аругих. Его заАачей является Аолжное «разграничение» борющихся интересов, то есть определение границ узаконенной свободы каждого человека и равная защита их всех. ${ }^{[6,148]}$

ОАнако если право не преАписывает нам цемей, то есть положительного содержания нашей Аеятельности, рассужаает Аалее В. С. Соловьев, то это содержание может быть мибо (1) задано нашими экономическими интересами, мибо (2) преАписано нравственностью. Право характеризуется абсоюютной универсацьностью своей формы, которая не сочетается с конкретным и случайным содержанием экономических интересов. Оно требует, так сказать, абсолютного содержания, которое может быть задано только абсолютной нравственностью. А высшей нормой абсолютной нравственности явмяется милосерАие или мюбовь.
При этом В. С. Соловьев выступал против принципа свободной воли как основы нравственности. Он писал: «Если бы человеческая воля была свободной, то есть совершенно произвольной, свобоАной от всех виАов Аетерминации, то она была бы свободной и от Аетерминации мюбыми нравственными соображениями, что сделало бы невозможным нравственное поведение, а теории нравственности - совершенно измишними». ${ }^{[7,319]}$ На самом Аеле, Аобавлял В. С. Соловьев, элемент свободы в человеческой воле можно Аопустить не в качестве объяснения нравственности, как думах И. Кант, а как объяснение безнравственности, потому что только выбор человеком зма может быть совершенно ничем не обоснован.

Из такого понимания соотношения права и нравственности могично также следовало следующее: «Чтобы быть нравственным, общество Аолжно основываться на свободном взаимном согласии, и это означает, что Аюбой общественный союз АОАжен быть Аобровольным, и что кажАый член Аанного общества сохраняет свое неотъемлемое право выхода. С Аругой стороны, общество не Аолжно быть безразлично к судьбе своих членов: его обязанность заключается в том, чтобы обеспечить каждому опреАеменный минимум благосостояния, необходимого Аля «Аостойного существования». ${ }^{[1,239-240]}$ При этом, как писац сам В.С. Соловьев, «требуется, чтобы всякий человек имем не только обеспеченные среАства к существованию ... и Аостаточный физический отАых, но чтобы он мог также пользоваться и Аосугом Аля своего Ауховного совершенствования». ${ }^{[7,380]}$ Эта формула, Аобавмял там же В. С. Сомовьев, преАназначена Аля определения не только необходимого общественного минимума, но также и максимума законных требований (если они не связаны с особыми заслугами). И хотя этот вывод был определенной новацией Аля конституционного правосознания того времени, он, тем не менее, был могичен: крайняя беАность и Аругие неблагоприятные социальные обстоятельства могут мегко созАать непреодолимые препятствия Аля реализации человеческих возможностей. Поэтому эти препятствия Аолжны быть устранены путем обеспечения кажАого человека не только формальной свободой, но и необходимой помощью в Аостойном осуществлении человеческого преАназначения.

Согласно В. С. Соловьеву, существенные различия межАу нравственностью и правом могут быть сведены к трем пунктам. Во-первых, нравственные требования не ограничены, в то время как правовые требования всегАа строго ограничены. Причина этого заключается в том, что нравственность всегАа 
стремится к совершенству, тогАа как право требует мишь «низшей, минимальной степени нравственного состояния $>$. Во-вторых, правовые требования всегАа четко определены: всегАа можно установить, были они исполнены или нет. В отличие от того, что нравственные требования из-за своей неограниченной природы мишены точности и определенности содержания и объема. Сам В. С. Соловьев считал этот момент отличительным положительным качеством права. И в-третьих, нравственность несовместима с принуждением, в то время как право Аолжно быть подкреплено силой. Выводом из этого анализа стало новое определение права (в смысле законной справеАливости, объеАиняющей объективный закон и субъективное право): «Право есть принуАительное требование реализации определенного минимацьного Аобра, или порядка, не Аопускающего известных проявмений зма». ${ }^{[7,409]}$ При этом В.С. Соловьёв вводит критерий реализации права в Аействительности в отличие от нравственности: «Важно тут, прежде всего, чтобы известные вещи фактически быми, и чтобы известных вещей фактически не бымо». $\left.{ }^{7}, 414\right]$

По В. С. Соловьеву, статутное (позитивное) право, кроме того, Аолжно характеризоваться слеАующим тремя признаками: (1) публичность, Аоведение до всеобщего сведения; (2) конкретность, то есть оно Аолжно разъяснить способы своего применения в конкретных скучаях, и наконец; (3) его применимость к существующим условиям и наАичие санкций на случай неисполнения. Очевидно, Аля обеспечения исполнения и совершенствования законов необходима организованная сила (вцасть). Такую вцасть можно опреАелить как «реацьное преАставительство права» или «дееспособную законность». «В простейшем практическом выражении смысл госуАарства состоит в том, что оно в своих преАелах подчиняет насилие праву, произвол законности, заменяя хаотическое и истребительное столкновение частных элементов природного человечества правильным порядком их существования, причем принуждение Аопускается мишь как среАство крайней необходимости, заранее определенное, закономерное и оправданное, поскольку оно исходит от общей и беспристрастной вмасти». ${ }^{[7,421]}$ Иначе говоря, у В. С. Соловьёва получается, что всякое государство есть правовое государство (Rechtstaat), поскольку Ааже в своем Аеспотическом варианте обеспечивает некоторый порядок, преодолевает гоббсовское естественное состояние войны всех против всех. И это бымо шагом в сторону правового позитивизма: оправАание Аобра у него переросло в оправдание государства.
Представляется, что спор Б. Н. Чичерина и В.С. Соловьева не потерял своей актуальности и в наши Ани, поскольку «специфика нынешнего исторического момента заключается в том, что официальная правовая Аоктрина, получившая закрепление в Конституции РФ, оказацась гуманистичнее все еще Аоминирующего в российской юриспруденции (как в теории, так и на практике) мегистского правопонимания, Аоставшегося ей в наслеАство от советского периода». ${ }^{[8,13]}$ Напомним, что согласно определению, принятому на первом Совещании по вопросам науки советского государства и права 1938 года под руководством А. Я. Вышинского, право - это «совокупность правии поведения, выражающих волю господствующего класса, установленных в законодательном порядке, а также обычаев и правиц общежития, санкционированных государственной вцастью, применение которых обеспечивается принудительной силой государства в целях охраны, закрепления и развития общественных отношений и ПоряАКов, выгоАНЫХ и УгОАНЫХ гОсПОАствУющемУ киассу $\gg .{ }^{[9,37]}$

По нашему мнению, Аһя того чтобы преодолеть госпоАство юриАического Позитивизма, необходимо отказаться от реАукции конституционализма к нормам и институтам конституционного права и эксплицировать аксиологическое содержание данной парадигмы через призму его базовых ценностей свободы и справеАливости. В широком смысле поА конституционализмом следует понимать публичноправовую этику (форму правосознания), а также АеАуцируемую из её исходных ценностей (архетипов правосознания) реацьную практику государственного строительства. Аанная форма правосознания считает возможным и необходимым строить на рационацьной основе систему государственного управления (взаимоотношений межАу гражАанином и вцастью), межАу самими гражАанами, а также межАу инАивиАом и обществом, и Ааже межАу суверенными госуАарствами. Конституционацизм исхоАит из признания равного Аостоинства за кажАым свободно опреАеляющимся (суверенным) субъектом социума (инАивиА, группа гражАан, нация) или межАународного сообщества (госуАарство).

Признание Аостоинства в Аанной парадигме реализуется через предикацию естественных и неотчужАаемых (что является правовой гарантией свободы разума и воли) прав (свободы Аелать или не Аелать что-либо) гражАанина (объединений гражАан, наций, государств) при условии признания послеАним (послеАними) и честного слеАования всей совокупности рационацьных правиц общественной, государственной и межАународной жизни. Иначе го- 
воря, конституционализм есть некал теоретическал парадигма правосознания, решающал задачу по разработке определенных принцииов справедливого устройства общественной жизни, которые позволяют обеспечить реализачию частной и публичной автономии для всех социальных субъектов. Аля него категории «свободы», «справеАливости» и «человеческого Аостоинства $\gg$ явмяются фундаментальными ценностями (архетипами).

Еще Аревние говорили, что omnis determinatio est negatio - всякое определение есть отрицание. В этой связи постановка проблематики свободы в философском и правовом Аискурсе, по нашему мнению, Аолжна звучать так: отрицанием чего является содержание понятия «свобода». Как справеАмиво пишет в этой связи 3. Бауман: «Свобода Аелит и разделяет. Свою привлекательность она черпает из разАичия. Некоторые мюАи могут быть свободны мишь постольку, поскольку существует форма зависимости, какой они стремятся избежать». ${ }^{[10,22]} \mathrm{Koн-}$ ституционализм как картина мира исходит из того, что пространство свободы возникает только вне сферы дискреции власти. Аля этой формы правосознания контракАикторность опПозиции свободы и вцасти пронизывает всю систему и все уровни общественного раздемения труаа в мюбом типе социальности (семье, первичном трудовом комлективе, конфессиональном союзе, племени, современном государстве и т.А.). Именно поэтому мюбую вмасть необходимо ограничивать и разАемять, так как этот общественный институт по своей внутренней $\Lambda$ гике тяготеет к всеобщности. Ибо по своей сути власть есть не что иное, как всего мишь монополизация некоторым социальным субъектом опредеменной общественной функции, а именно функции рационального целеполагания и контроля (то есть управления), которые явмяются основными характеристиками общественного бытия. Эта имманентная характеристика власти покучила свое отражение и закрепление в юридической и политической науках в понятии «суверенитета».

Всеобщность вмасти как акциденции (само) управления обществом может быть ограничена только институционально: или траАицией, или правом. ПослеАнее в конституционном смысле есть не что иное, как рационализация с помощью Аогматического метода вцастных отношений на основе норм морахи и ценностей правосознания, интерсубъективно принятых Аанным социальным субъектом (инАивиАом, родом, племенем, обществом, религиозным сообществом и т.А.). А правовая и моральная оценка, как известно, возможна тоцько в отношении поступков свободной и ответственной (Аеликтоспо- собной, говоря юриАическим языком) мичности, обладающей объективным Аостоинством, то есть интерсубъективной значимостью в конкретном социуме. В противном случае мы не вправе требовать от субъекта ответственного правового повеАения. Иначе говоря, без признания достоинства (ими правосубъектности, согласно юридической терминологии) человека не возможна объективация его свободы. Именно поэтому конституционализм сопрягает категорию «свободы» и категорию «достоинство » человеческой мичности в неразрывном аксиологическом синтезе.

На этапе становцения буржуазного общества первой его программой, основанной на принципах конституционацизма, стала теория верховенства права (ики правого государства). Под «правовым государством» в данной парадигме понимается государство, имеющее своей целью создание институииональных предпосылок для признания равного человеческого достоинства за каждым гражданином через обеспечение реализачии его права на частную и публичную автономию. Аля решения этой заАачи быми разработаны определенные принципы. Во-первых, это принцип разАеления вмастей, то есть разАеленного существования законодательной, исполнительной и судебной власти. Во-вторых, принцип независимости суАа, согласно которому как процесс суАопроизвоАства, так и принимаемое суАом решение Аолжно быть полностью независимым как от воздействия вышестоящих инстанций, так и Аюбого возАействия извне. В-третьих, это принцип подзаконности аАминистративного управления, которая искцючает возможность осуществления такой аАминистративной Аеятельности, которая не базируется на нормах существующего законодательства, а самое главное она не Аолжна противоречить базовым ценностям конституционализма. Иначе говоря, аАминистративная Аеятельность не может ограничивать свободу и умалять человеческое Аостоинство за исключением экстремальных общественных ситуаций (война, чрезвычайное положение в связи с какими-нибудь природными катаклизмами и т.п. ). В-четвертых, это принцип судебной защиты, который гарантирует возможность выигрыша судебного иска против мюбого противоправного аАминистративного Аействия. В-пятых, это принцип юриАической ответственности госуАарственных органов, обеспечивающий право на имущественную компенсацию постраАавшим вслеАствие как законной, так и противозаконной аАминистративной деятельности. ОчевиАно, что эти принципы внутренне взаимосвязаны и не могут функционировать отАельно Аруг от Аруга. 
ОАнако нельзя, как это Аелают многие современные российские юристы, редуцировать все соАержание понятия правовое государство к вышеперечисленным принципам. Например, $\Lambda$. С. Мамут полагает: «Мир права «не оборудован» поА воцарение в нем «социальной справеАливости» (фактического равенства). Он строится как совокупность горизонтальных симметричных отношений межАу участниками универсального процесса социального взаимодействия >. СправеАливость - это формальное равенство, а социальная уязвимость некоторых категорий гражАан не возмагает на государственноорганизованное общество правовое обязательство обеспечивать каждому «достойную жизнь». ${ }^{[1,7]}$ Это всего мишь признаки формамьной законности, которыми, как показали теория и практика мнимого конституционацизма во многих странах, могут мишь отлично управлять и извращать автократы и бюрократы всех мастей. «Истинный смысл, истинная суть правового государства - это реальная, материальная справеАливость. Государство является воистину правовым мишь в том скучае, если оно - как в своих структурах, так и в своей Аеятельности направлено на обеспечение справеАливости». $[12,170]$ Можно с уверенностью сказать, что илея социальной справеАливости является конституирующей в процессе солидаризации общества на протяжении всей человеческой истории. Именно представление об общественном отношении как справедливом, то есть интерсубъективно признаваемом, обеспечивает мегитимацию политических институтов и мидеров. Иначе говоря, идея социальной справеАливости осуществляет ценностную интеграцию всех членов общества. Поэтому вышеуказанные пять принципов формацьной законности явцяются всего мишь среАством на службе илеи реальной справеАливости, в практическом осуществлении которой и оправАывается идея правового государства как таковая.

Безусловно, в кажАом типе общества существует свое понимание идеи социальной справеАливости. В этой связи социальная справеАливость вступает как конкретно-историческая правовая и моральная норма признания человеческого Аостоинства. Подобно тому, как наука открывает разцичные формы истины, а не истину, как некий Абсолют, так и конституционализм в конкретных исторических обстоятельствах рационально (Аискурсивно) вырабатывает форму социальной справеАливости. Говоря философским языком, социальная справеАливость суть атрибут, а не субстанция, она есть ценностное измерение мегитимации власти и социального поряАка. С точки зрения конституционализма, социиално справедлиым является такое общественное состояние (положение закона, функционирование помитического института), которое не ограничивает, а лучше расширяет, пространство свободь индивида, сферу его частной и публчной автономии.

Формирование индустриацьного общества в XIX веке привело к ситуации, когАа преАставление о справеАливости, теоретически осмысленное в теории правового госуаарства, которое в свое время объединило третье сословие и повело его на штурм традиционных и монархических институтов Старого порядка, уже не могло быть реализовано. Создание крупных заводов и фабрик потребовано концентрации в городах инАивиАов, проАающих еАинственную свою собственность - свою способность к труАу, то есть рабочую сику и получающих взамен все, что необходимо Аля жизни - жилье, пищу и т.А. Аишенные траАиционной социальной защиты со стороны местной общины (сосеАской солидарности) и не имеющие частной собственности, эти инАивиАы в глазах буржуазии были также Аишены и человеческого Аостоинства. И именно поэтому они могми быть поАвергнуты экспиуатации. Пауперизация, так ярко описанная К. Марксом, вызвала киассовую борьбу за утверждение человеческого Аостоинства Аюдей наемного труда во имя справеАливости. И не случайно эта борьба велась, прежде всего, за политические права, а потом уже за социацьные, экономические и иные права, так как в конституционацизме частная и публичная автономия тесно взаимосвязаны.

Поскольку гражАан как собственников становилось все меньше, постольку общество, чтобы избежать Аесолидаризации и полного саморазрушения, во имя справеАливости и свободы Аля всех гражАан было вынужАено отказаться от идеи государства как «ночного сторожа» и созАать его новый тип, получивший в научной митературе название «соииального государства». Такое госуАарство Аолжно было обеспечить воспроизводство гражАанина как человека с чувством Аостоинства, способного к частной и публичной автономии, из массы мюАей, Аишенных собственности и живущих наемным трудом. Аля того чтобы появилась возможность вкАючения Аишенных собственности гражАан в демократический процесс, в рамках парадигмы конституционализма потребовалось переосмыслить и переформулировать ряА принципиальных «естественных прав» чемовека - право на жизнь и право на собственность, а также и концепцию права как такового.

ПрежАе всего, стацо ясно, что Аця гражАан, существующих за счет продажи своей рабочей силы, право на жизнь может быть реализовано только в виде права на достойный труА. Именно поэтому 
все мероприятия по гуманизации труда начинались во всех странах с деятельности фабричных инспекций.

Аамее бымо установмено, что матрица индивидуального и свободного трудового контракта не создает равноправия сторон (рабочего и капиталиста) в Аоговоре, хотя именно на этом постулате Аержалось тогдашнее право. Такое равенство может быть Аостигнуто только через признание реальности и значимости трудового комлектива, который Аает возможность отАельному рабочему реализоваться как полноценному субъекту в отношениях с работодателем. Поэтому во всех развитых странах неизбежно возникали профсоюзы, способные на равных вести переговоры с предприниматемями, а также появицся механизм комлективного трудового Аоговора, гАе опреАелялись базовые условия по найму.

Вершиной процесса пересмотра основных Аогматов «классического» правового Аискурса стала система обязательного коммективного страхования от рисков наемного труда (внезапной утраты трудоспособности, старости, безработицы и Ар.). Теперь в системе обязательного социацьного страхования индивидуальный риск покрывался за счет того, что он бым включен в систему комлективной защиты. Но самое главное заключалось в том, что эта система позволяла преодолеть Аихотомию автономная собственность/гетерономный труА. «Решение социацьного ${ }^{\text {[рабочего - В.в.К.] }}$ вопроса состояло не в том, чтобы отменить оппозицию собственник/несобственник, а чтобы переопределить её, то есть противопоставить частной собственности Аругой тип собствен- ности, а именно общественную, позволяющей получить защиту, не имея частной собственности». ${ }^{13,343]}$

Появцение собственности общественных фонАов, управляемых государством, созАало новую историческую ситуацию, когАа взносы в общие фонды были обязательны и при этом Аавали неотчужааемое право, которое нельзя бымо вывести на рынок. Зарпиата перестала явцяться только вознаграждением рабочему, эквивацентом стоимости его рабочей симы. Отныне она содержала в себе часть, преАставмявшую собой своеобразную труАовую ренту Аля внепроизводственных ситуаций. Тем самым страхование вписывало наемного рабочего в правовой порядок. С аксиологической точки зрения, социальное государство можно определить как такое государство, которое публино-властным образом гарантирует каждому гражданину определенные стандарты материальных условий жизнедеятельности, позволяющие ему реализовывать свое право на частную и публичную автономию. ${ }^{14,152-163]}$

Таким образом, Аимемма свободы и справеАливости, вокруг которой шла полемика Б. Н. Чичерина с В. С. Соловьевым, с точки зрения аксиологического конституционацизма, явмяется можной. Сочетание теоретически выраженных иенностей свободы и достоинства человека с требованием честности и справедливости предотвращает превращение конституционализма в некий набор мертвых догм и институтов конституционного права, поскольку требует давать на нюбые вызовы со стороны постоянно изменяющейся соииальности только такие ответы, которые сохраняют, а мучше растиряют сферучастной и публичнй автономии.

\section{БИБАИОГРАФИЯ}

1. Валицкий А. Философия права русского миберализма. М.: Мысль, 2012. С.84.

2. Чичерин Б. Н. Собственность и государство. Т. 1. М.: Тип. Мартынова и Ко, 1883. С.3-9.

3. Чичерин Б.Н. Философия права. М.: Типо-лит. т-ва И. Н. Кушнерев и Ко, 1900. С.50-52.

4. Чичерин Б.Н. О народном преАставительстве. М.: ИзА-во Сытина, 1866. С.175.

5. Чичерин Б. Н. Курс государственной науки. Т. 1. М.: Типография товарищества И. Н. Кушнерев и Ко, 1894. C.175.

6. Соловьев В. С. Критика отвлеченных начал// Соловьев В. С. Собр. соч. в 9-ти томах. Т. 2. СПб.: ИзА-во Т-ва «Общественная Польза», 1901. С. 144.

7. Соловьев В. С. Оправдание добра // Соловьев В. С. Собр. соч. в 9-ти томах. Т. 8. СПб.: ИзА-во Т-ва «Общественная Польза», 1901. С.319.

8. Мапаева В.В. Типы правопонимания: правовая теория и практика. М.: Российская академия правосуАия, 2012. С. 13.

9. Основные задачи науки советского права: Материалы первого Совещания научных работников права. 16-19 июля 1938 г. М., 1938. С. 37.

10. Бауман 3. Свобода. М.: Новое издательство, 2006. С.22.

11. Мамут А. С. Социальное государство с точки зрения права // Государство и право, 2001, № 7. С. 7.

12. Хубер Э. Р. Правовое и социальное государство в современном индустриальном обществе // Политическая философия в Германии: Сб. ст. М.: Современные тетради, 2005. С. 170. 
13. Кастель Р. Метаморфозы социального вопроса. Хроника наемного труда. СПб.: Алетейя, 2009. С. 343.

14. Кочетков В.В.Конституционализм и социальный вопрос// ПОАИС. 2012. № 2. С. 152-163.

\section{REFERENCES (TRANSLITERATED)}

1. Valitskii A. Filosofiya prava russkogo liberalizma. M.: Mysl', 2012. S.84.

2. Chicherin B. N. Sobstvennost' i gosudarstvo. T.1. M.: Tip. Martynova i Ko, 1883. S.3-9.

3. Chicherin B. N. Filosofiya prava. M.: Tipo-lit. t-va I. N. Kushnerev i Ko, 1900. S.50-52.

4. Chicherin B. N. O narodnom predstavitel'stve. M.: Izd-vo Sytina, 1866. S.175.

5. Chicherin B. N. Kurs gosudarstvennoi nauki. T.1. M.: Tipografiya tovarishchestva I. N. Kushnerev i Ko, 1894. S.175.

6. Solov'ev V.S. Kritika otvlechennykh nachal// Solov'ev V. S. Sobr. soch. v 9-ti tomakh. T.2. SPb.: Izd-vo T-va 'Obshchestvennaya Pol'za', 1901. S. 144.

7. Solov'ev V.S. Opravdanie dobra // Solov'ev V. S. Sobr. soch. v 9-ti tomakh. T.8. SPb.: Izd-vo T-va 'Obshchestvennaya Pol'za', 1901. S.319.

8. Lapaeva V.V. Tipy pravoponimaniya: pravovaya teoriya i praktika. M.: Rossiiskaya akademiya pravosudiya, 2012. S. 13.

9. Osnovnye zadachi nauki sovetskogo prava: Materialy pervogo Soveshchaniya nauchnykh rabotnikov prava. 16-19 iyulya 1938 g. M., 1938. S. 37.

10. Bauman Z. Svoboda. M.: Novoe izdatel'stvo, 2006. S.22.

11. Mamut L. S. Sotsial'noe gosudarstvo s tochki zreniya prava // Gosudarstvo i pravo, 2001, № 7. S. 7.

12. Khuber E. R. Pravovoe i sotsial'noe gosudarstvo v sovremennom industrial'nom obshchestve // Politicheskaya filosofiya v Germanii: Sb. st. M.: Sovremennye tetradi, 2005. S. 170.

13. Kastel' R. Metamorfozy sotsial'nogo voprosa. Khronika naemnogo truda. SPb.: Aleteiya, 2009. S. 343.

14. Kochetkov V.V. Konstitutsionalizm i sotsial'nyi vopros// POLIS. 2012. № 2. S. 152-163. 